\title{
Human Respiratory Syncytial Virus
}

National Cancer Institute

\section{Source}

National Cancer Institute. Human Respiratory Syncytial Virus. NCI Thesaurus. Code

C14267.

A negative-sense, enveloped RNA virus. The virion is variable in shape and size with an average diameter of between 120 and $300 \mathrm{~nm}$. 